\title{
Malignant Mesenchymal Tumor of the Breast: Primary Chondrosarcoma
}

\author{
Emin Gurleyik $^{\mathrm{a}} \quad$ Umran Yildirim $^{\mathrm{b}} \quad$ Omer Gunal $^{\mathrm{a}} \quad$ Mevlut Pehlivan $^{\mathrm{a}}$ \\ a Department of Surgery, \\ ${ }^{\mathrm{b}}$ Department of Pathology, Medical Faculty, Duzce University, Turkey
}

\section{Key Words \\ Breast · Chondrosarcoma}

\section{Summary}

Background: Primary mesenchymal tumors are an extremely rare malignancy of the breast. Case Report: A 52-year-old woman presented with a rapidly growing breast mass. Physical examination established a large and round mass with regular margins in the upper-outer quadrant of the right breast. Ultrasound showed a hypoechoic solid mass $(41 \times 36 \mathrm{~mm})$ with lobulated contours. Mammography revealed a hyperdense and relatively regular-shaped mass giving the impression of a benign tumor. However, a pathologic report of atypical cells after fine needle aspiration necessitated surgical excision. The mass was removed with a wide local excision. The tumor was diagnosed as a high-grade chondrosarcoma of the breast by histopathological analysis. Following the final diagnosis, we performed a modified radical mastectomy based on the knowledge that this malignancy is generally refractory to radiotherapy. The regional lymph nodes and local adjacent tissues were free of metastasis. The tumor was negative for estrogen and progesterone receptors as well as HER2. Conclusion: Chondrosarcoma tends to grow rapidly. Physical examination usually reveals a large, round mass. The tumor is regular-shaped, round, and complex echoic on mammography and ultrasound. It usually does not invade regional structures. Surgery remains the only effective treatment.

\author{
Schlüsselwörter \\ Brust . Chondrosarkom
}

\section{Zusammenfassung}

Hintergrund: Primäre mesenchymale Tumoren der Brust sind äußerst selten. Fallbericht: Eine 52 Jahre alte Frau stellte sich mit einem schnell wachsenden Tumor der Brust vor. Die klinische Untersuchung bestätigte eine große und runde Wucherung mit gleichmäßigen Rändern im oberen äußeren Quadranten der rechten Brust. Ultraschall zeigte einen echoarmen, festen Tumor $(41 \times$ $36 \mathrm{~mm}$ ) mit lobulären Konturen. Die Mammografie ließ eine verhältnismäßig gleichmäßig geformte Wucherung mit erhöhter Dichte erkennen, die einen gutartigen Tumor vermuten ließ. Die pathologische Untersuchung eines Feinnadelaspirationsbiopsates ergab jedoch untypische Zellen und indizierte eine chirurgische Exzision. Der Tumor wurde durch lokale Exzision im Gesunden entfernt. Die histopathologische Analyse ergab ein hochgradig malignes Chondrosarkom der Brust. Aufgrund der endgültigen Diagnose und da dieser Tumor üblicherweise nicht strahlenempfindlich ist, führten wir eine modifiziert radikale Mastektomie durch. Die regionalen Lymphknoten und das benachbarte Gewebe waren frei von Metastasen. Der Tumor war Östrogen- und Progesteron-Rezeptor- sowie HER2-negativ. Schlussfolgerung: Das Chondrosarkom neigt zu schnellem Wachstum. In der klinischen Untersuchung zeigt es sich als größere, runde Wucherung. Mammografie- und Ultraschallaufnahmen zeigen einen gleichmäßigen, runden Tumor mit komplexem Echosignal. Normalerweise greift er nicht auf benachbarte Strukturen über. Die chirurgische Entfernung stellt die einzige wirksame Behandlung dar.

\section{KARGER}

Fax +497614520714

Information@Karger.de

www.karger.com (c) 2009 S. Karger GmbH, Freiburg

www.karger.com/brc 


\section{Introduction}

Malignant tumors originating from mesenchymal tissue occur very rarely in the breast. The metaplastic carcinomas which are characterized by a combination of mesenchymal and epithelial components are uncommon malignancies of the breast [1]. Pure primary sarcomas are the rarest malignancies in mammary tissue. The chondrosarcoma is a typical example of these rarest tumors of the mesenchymal tissue. Less than 10 cases have been published in the literature [2-4]. We report a new case of primary chondrosarcoma of the breast.

\section{Case Report}

A 52-year-old postmenopausal woman (married with 2 children) presented in our department with a complaint of a breast mass which had rapidly grown for 3 months. Breast palpation revealed a painless, mobile, relatively regular-shaped, hard, and large mass of $4 \mathrm{~cm}$ in the upper-outer quadrant of the right breast, at $3 \mathrm{~cm}$ from the areola margin between the 9 and 10 o'clock radius. The right axilla was clinically negative. Ultrasound showed a hypoechoic solid mass $(41 \times 36 \mathrm{~mm})$ with posterior enhancement and lobulated contour, including cystic components. Mammography showed a large, hyperdense, and relatively round mass (fig. 1). Fine needle aspiration (FNA) cytology revealed atypical cells which were suspicious of a malignant tumor.

We planned a breast-conserving operation and performed a wide local excision of the mass without axillary dissection. Histopathological examination: On serial slicing, a $5 \times 3 \times 5 \mathrm{~cm}$ grey-white mass with irregular margins including cystic, hemorrhagic, and necrotic areas was macroscopically observed. A high-grade tumor consisting of cartilaginous tissue was diagnosed by microscopic examination. Malignant cells which had hyperchromatic and pleomorphic nucleoli showed multiple locations in a single lacuna. The tumor was surrounded by breast tissue. The pathologist observed the infiltration of malignant cells into the breast tissue between lobular structures (fig. 2). Receptor analysis was negative for estrogen and progesterone receptors as well as HER2. Further careful and detailed examination did not show malignant epithelial components. The diagnosis was high-grade chondrosarcoma.

After the pathologic diagnosis of breast chondrosarcoma, other foci of cartilaginous tumor were searched in the entire body by proton emission tomograpy (PET) scan which did not show other foci of malignancy.

After the diagnosis of chondrosarcoma, we performed a modified radical mastectomy (with level I axillary dissection). On histopathological examination the pathologists did not find any residual malignant cells in the mastectomy specimen. The excised lymph nodes were free of metastases.

\section{Discussion}

This paper discusses one of the rarest mesenchymal malignancies of the breast, primary chondrosarcoma. Other types of pure sarcoma, such as spindle cell sarcoma, neuroectodermal tumor, angiosarcoma etc., have also been reported [5, 6].

The history of the patient has an important feature as the mass had grown rapidly without systemic and deleterious effect on the patient's health status. These tumors tend to grow rapidly and present themselves as a mass for a short duration $[2,3,6]$.

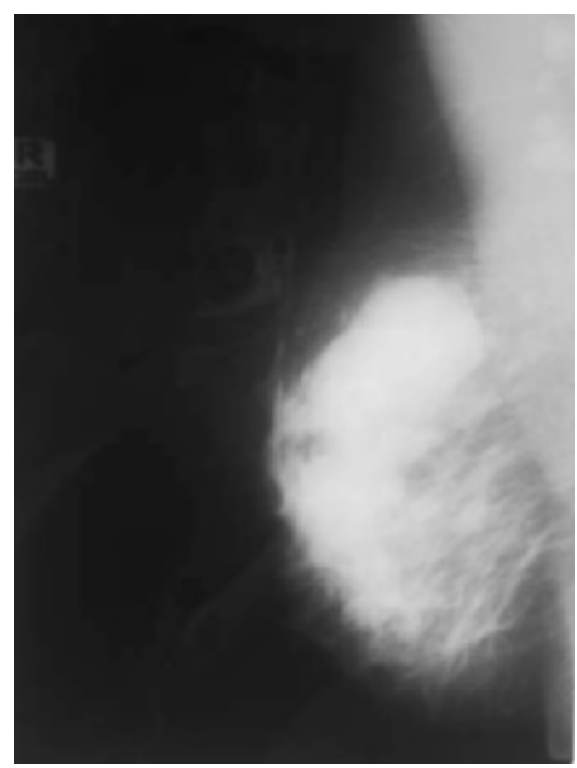

Fig. 1. Mammography shows a round and regular-shaped hyperdense tumor.

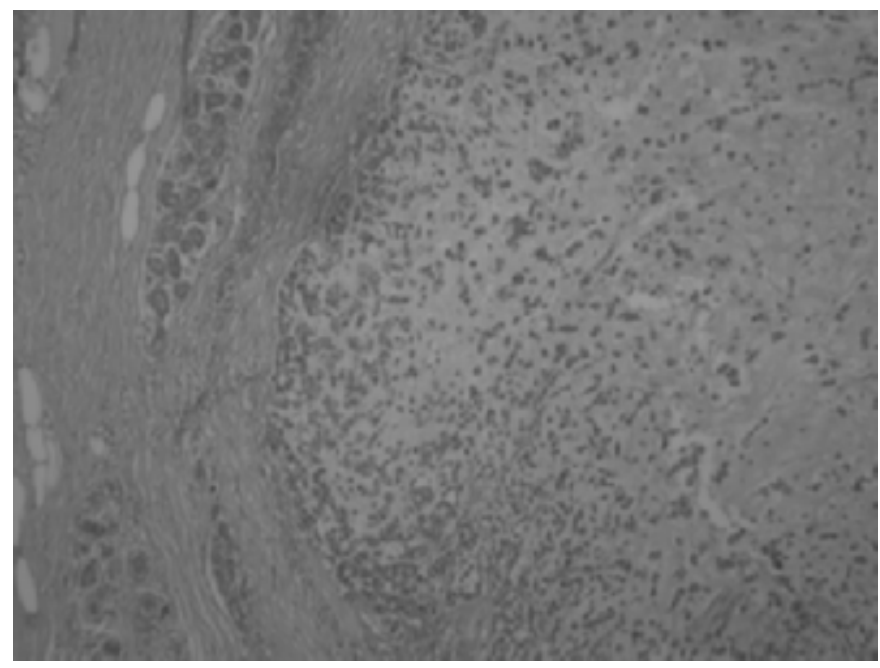

Fig. 2. Nodular arrangement of tumor tissue near the breast lobules $(\mathrm{HE} \times 10)$.

A large and round mass with relatively regular margins and without a sign of regional invasion was detected by palpation. These findings appear as important features of this large tumor. Previous reports also pointed out that these large tumors do not generally invade skin and regional lymph nodes despite their locally advanced nature $[2-4,6]$.

A relatively circumscribed, well demarcated mass, as in our patient, is an imaging characteristic of a pure mesenchymal or a metaplastic carcinoma with sarcomatoid differentiation. It has been reported that imaging studies seldom led to the diagnosis of sarcoma in a suspected benign lesion. The mass is complex echoic on ultrasound and shows round hyperdense opacity on mammography [4, 6, 7].

Atypical cells in FNA cytology showing features suspicious of malignancy led us to surgical excision. The pleomorphic and bizarre cellular features can suggest the diagnosis of 
metaplastic and pure sarcomas of the breast. The establishment of a diagnosis of sarcoma is generally difficult by FNA biopsy $[5,6,8]$.

The very limited number of such cases does not permit us to establish an appropriate therapeutic approach. Chondrosarcoma in common locations is generally known as refractory to all types of conventional chemotherapy and radiotherapy. Surgery remains the only effective treatment $[5,9]$. Despite the satisfactory technical and esthetic results of the breastconserving surgery, the final diagnosis of chondrosarcoma and its resistance to radiotherapy forced us to perform a modified radical mastectomy. Despite the knowledge (based on very limited case reports) of low incidence of axillary metastasis of primary sarcoma of the breast, a level I axillary dissection was part of the operation because this large tumor was located in the upper-outer quadrant adjacent to the axilla.

No metastasis in axillary lymph nodes despite larger tumor and hormone receptor negativity was also confirmed as a pathologic characteristic by previous reports. Pure chondrosarcoma and metaplastic cancer of the breast rarely invade axillary lymph nodes and are generally hormone receptor-negative $[1,2,4,10]$.

This extremely rare tumor tends to grow rapidly, and it is usually large at first physical examination. A large, round, hyperdense, and complex echoic mass with regular margins gives the impression of a benign tumor on mammography and ultrasound. Despite its large size, it does not invade local and regional structures. High-grade chondrosarcoma is generally refractory to chemotherapy and radiotherapy, and surgery remains the only effective treatment.

\section{Conflict of Interest}

The authors declared no conflict of interest.

\section{References}

1 Pezzi CM, Patel-Parekh L, Cole K, Franko J, Klimberg VS, Bland K: Characteristics and treatment of metaplastic breast cancer: analysis of 892 cases from the National Cancer Data Base. Ann Surg Oncol 2007;14:166-173.

2 Beltaos E, Banerjee TK: Chondrosarcoma of the breast. Report of two cases. Am J Clin Pathol 1979; 71:345-349.

3 Gupta S, Gupta V, Aggarwal PN, Kant R, Khurana N, Mandal AK: Primary chondrosarcoma of the breast: a case report. Indian J Cancer 2003;40:77-79.

4 Verfaillie G, Breucq C, Perdaens C, Bourgain C, Lamote J: Chondrosarcoma of the breast. Breast J 2005;11:147-148.
5 Cil T, Altintas A, Pasa S, Buyukbayram H, Isikdogan A: Primary spindle cell sarcoma of the breast. Breast Care 2008:3:197-199.

6 Thomas A, Blohmer JU, Turzynski A, Sezer O, Fischer T, Thiel G, Dietel M, Lichtenegger W, Kümmel S: Peripheral neuroectodermal tumor (PNET) of the breast - a 6-year follow-up. Breast Care 2006;1:324-327.

7 Shin HJ, Kim HH, Kim SM, Kim DB, Kim MJ, Gong G, Im SA, Cha ES: Imaging features of metaplastic carcinoma with chondroid differentiation of the breast. AJR Am J Roentgenol 2007;188:691-696.
8 Silverman JF, Geisinger KR, Frable WJ: Fine-needle aspiration cytology of mesenchymal tumors of the breast. Diagn Cytopathol 1988;4:50-58.

9 Cleton-Jansen AM, van Beerendonk HM, Baelde HJ, Bovée JV, Karperien M, Hogendoorn PC: Estrogen signaling is active in cartilaginous tumors: implications for antiestrogen therapy as treatment option of metastasized or irresectable chondrosarcoma. Clin Cancer Res 2005;11:8028-8035.

10 Beatty SD, Atwood M, Tickman R, Reiner M Metaplastic breast cancer: clinical significance. Am J Surg 2006;191:657-664. 